\title{
DETERMINAÇÃO DOS PERFIS DE ERIC-PCR DE Escherichia coli E E. coli 0157:H7 ISOLADAS EM MEIAS-CARCAÇAS BOVINAS
}

JOICE VINHAL COSTA*

IOLANDA APARECIDA NUNES**

LEONARDO FRANÇA***

\begin{abstract}
O presente trabalho objetivou identificar os perfis de ERIC-PCR em E. coli e E. coli $\mathrm{O} 157: \mathrm{H7}$, isoladas de superfícies de meias-carcaças quentes e resfriadas de bovinos de dois matadouros-frigoríficos do estado de Goiás, além de verificar a capacidade de discriminação dessa metodologia. A técnica de ERIC-PCR foi utilizada para a caracterização molecular das 111 amostras analisadas, sendo obtidos 32 perfis distribuídos em 90 cepas de E. coli e oito perfis distribuídos em 16 cepas de E. coli O157:H7. Do total de amostras, duas cepas de E. coli e cinco de E. coli O157:H7 eram não tipáveis. Os perfis de ERIC-PCR de E. coli variaram de um a 18 fragmentos. Obteve-se alta discriminação entre as cepas de E. coli e E. coli 0157:H7 por ERIC-PCR, cujo índice foi de 0,96.
\end{abstract}

PALAVRAS-CHAVE: CARACTERIZAÇÃO MOLECULAR; CARNE; E. COli PATOGÊNICA.

* $\quad$ Professora, Instituto Federal Goiano, Campus Urutaí, GO (e-mail: joicevinhal@gmail.com).

** Professora, Centro de Pesquisa em Alimentos, Escola de Veterinária, Universidade Federal de Goiás, Goiânia, GO (e-mail: inag@terra.com.br).

*** Professor, Faculdade FAMA, Mineiros, GO (e-mail: leonardo.102@gmail.com). 


\section{INTRODUÇÃo}

Nas últimas décadas foram identificadas novas espécies de microrganismos patogênicos e verificado o reaparecimento de agentes já conhecidos, como também foram desenvolvidos métodos mais eficazes para seu isolamento e detecção. Mudanças demográficas e alterações nos hábitos alimentares têm provocado modificações tecnológicas na indústria com relação à formulação, ao processamento e à distribuição dos alimentos. Essas modificações, associadas à habilidade dos microrganismos de se desenvolverem rapidamente e se adaptarem ao ambiente têm acarretado novos desafios para o sistema alimentar (ROWLANDS et al., 2007).

$\mathrm{O}$ isolamento e a identificação de $E$. coli $\mathrm{O} 157: \mathrm{H} 7$ em fezes de bovinos em várias regiões do Brasil devem ser considerados, uma vez que a carne pode ser contaminada nos matadourosfrigoríficos durante a evisceração dos animais, mediante contato com a pele previamente contaminada com fezes ou por contaminação cruzada (STELLA et al., 2008).

Adetecção de E. coli O157:H7 em superfície de meias-carcaças bovinas quentes e resfriadas em matadouros-frigoríficos de grande porte no Estado de Goiás, cuja produção é voltada para o mercado externo, é preocupante e serve de alerta às autoridades sanitárias, quando considerada a gravidade das complicações provocadas pela doença (RIOS, 2005).

Relatos de casos esporádicos de diarréia associados à E. coli O157:H7, ocorridos no Brasil, mostram a necessidade de efetiva investigação epidemiológica, mediante técnicas laboratoriais avançadas para a caracterização da bactéria, assim como a busca de notificações dos casos pelos médicos e a análise laboratorial dos alimentos ingeridos.

A descoberta de que os genomas procarióticos continham sequências repetitivas de DNA expandiu as metodologias de biologia molecular para estudos de variabilidade clonal em muitas espécies bacterianas, incluindo E. coli (CHANSIRIPORNCHAI et al., 2001). Em algumas técnicas moleculares de tipagem baseadas em PCR são utilizados "primers" homólogos a essas sequências, que após a amplificação geram perfil específico para cada amostra bacteriana (VERSALOVIC, KOEUTH e LUPSKI, 1991). Algumas sequências repetitivas de DNA têm sido estudadas mais detalhadamente na bactéria E. coli (CHANSIRIPORNCHAl et al., 2001), sendo denominadas Sequências Consensuais Intergênicas Repetitivas Enterobacterianas (ERIC).

O número de cópias de sequências ERIC varia conforme a espécie do microrganismo. Em E. coli, alguns autores estimam esse número em 30 cópias (DUCHAD, RUSNIOK e FRANGEUL, 2003), enquanto outros relatam números variando de 30 a 50 (MARTIN et al., 1992). As sequências ERIC diferenciam-se de outras sequências repetitivas presentes em variadas espécies e foram primeiramente descritas em E. coli, Salmonella Typhimurium e demais membros da família Enterobacteriaceae. Estão presentes apenas em regiões intergênicas, dentro de regiões transcritas (HULTON, HIGGINS e SHARP, 1991).

A técnica de ERIC-PCR tem sido utilizada como alternativa aos métodos de tipagem molecular convencionais para caracterizar enterobactérias, em especial E. coli de origem aviária, discriminando cepas não patogências e patogênicas (SILVEIRA, SILVA e CONTRERAS, 1999).

$O$ presente estudo teve como objetivo geral verificar a diversidade genética de $E$. coli e $E$. coli O157:H7 em meias-carcaças bovinas quentes e resfriadas de dois matadouros-frigoríficos de grande porte de Goiânia, por meio da técnica de ERIC-PCR.

\section{MATERIAL E MÉTODOS}

\subsection{AMOSTRAGEM}

Foram analisadas 111 cepas, sendo 90 de E. coli com sorovar não identificado e 21 cepas de E. coli $\mathrm{O} 157: \mathrm{H} 7$, isoladas de superfície de meias-carcaças quentes e resfriadas de bovinos abatidos em dois matadouros-frigoríficos de grande porte localizados em Goiânia (GO), submetidos ao Serviço de Inspeção Federal (SIF).

Das 90 cepas de $E$. coli analisadas, 51 foram isoladas no matadouro-frigorífico A, enquanto que as outras 39 foram isoladas no matadouro-frigorífico B. No matadouro-frigorífico A, nove cepas pertenciam a três meias-carcaças quentes e 42 cepas a sete meias-carcaças resfriadas. No matadouro-frigorífico B, dez cepas foram isoladas de quatro meias-carcaças resfriadas e 29 cepas de duas meias-carcaças quentes.

Do total de 21 cepas de E. coli O157:H7, 15 pertenciam ao matadouro-frigorífico A e seis 
cepas ao matadouro-frigorífico B. No matadouro-frigorífico A, E. coli O157:H7 foi isolada de três meiascarcaças quentes e de seis resfriadas, enquanto que no matadouro-frigorífico $B$, três cepas foram isoladas de uma meia-carcaça quente e as outras três cepas de uma meia-carcaça resfriada.

Utilizou-se o par de oligonucleotídeos para E. coli O157:H7, com as sequências (5’ AAGCTCCGTGTGCCTGAA ‘3) e (5’ GTAGGGAAGCGAACAGAG '3) (WANG LUO e ROEDER, 1997), cujo gene-alvo é o hlyA.

Para a extração de DNA, as culturas estocadas a $-20^{\circ} \mathrm{C}$ em caldo Luria-Bertani (LB) suplementado com $12 \%$ de glicerol foram inoculadas em ágar MacConkey para certificação da pureza e incubadas a $37^{\circ} \mathrm{C} / 24 \mathrm{~h}$. Uma colônia lactose positiva de cada placa foi inoculada em $5 \mathrm{~mL}$ de Caldo LB e incubada a $37^{\circ} \mathrm{C} / 18 \mathrm{~h}$ em estufa BOD. Após esse período, cada colônia foi centrifugada a $10.000 \mathrm{rpm} / 20 \mathrm{~min}$ a $4^{\circ} \mathrm{C}$, sendo o sobrenadante descartado e o sedimento ressuspendido em $567 \mu \mathrm{L}$ de tampão tris EDTA (10 mM Tris, 1mM EDTA, pH 8,0) para extração do DNA genômico, realizada pela metodologia descrita por Alsubel et al. (1992) com algumas modificações (NUNES, 1999). Após ser seco ao ar, o "pellet" de DNA obtido foi solubilizado em $100 \mu \mathrm{L}$ de tampão TE (pH $8,0)$ e armazenado a $-20^{\circ} \mathrm{C}$.

A qualidade e a concentração do DNA foram verificadas em gel de agarose a $0,8 \% \mathrm{em}$ 0,5 XTBE, sendo a eletroforese realizada a 80V/1h em tampão $0,5 \mathrm{XTBE}(\mathrm{pH} 8,0)$. O gel de agarose foi corado com brometo de etídio $(0,5 \mathrm{mg} / \mathrm{L})$, visualizado em luz ultravioleta (UV) e posteriormente fotografado para documentação. A partir das concentrações estimadas, mediante comparação visual com diluições do $\lambda$-DNA em concentrações conhecidas, foram preparadas diluições do DNA tampão TE $(\mathrm{pH} 8,0)$ de forma a se obter $100 \mathrm{ng} / 5 \mu \mathrm{L}$ para amplificação.

Ato contínuo adotou-se a técnica de ERIC-PCR, a qual foi realizada em conformidade com o proposto por Versalovic, Koeuth e Lupski (1991). Para amplificação utilizou-se o par de "primers" ERIC1R (5'-ATGTAA GCT CCT GCG GAT TCAC-'3) e ERIC 2 (5'-AAF TAA GTG ACT GCG GTGAGC G-3) (INVITROGEN). A mistura da reação consistiu em 100 ng de DNA, tampão de PCR 1X, dNTP, Taq DNA Polimerase Recombinante Brasileira. A amplificação foi realizada em termociclador com desnaturação inicial a $95^{\circ} \mathrm{C} / 7 \mathrm{~min}$, seguindo 30 ciclos de desnaturação a $94^{\circ} \mathrm{C} / 1 \mathrm{~min}$, anelamento a $52^{\circ} \mathrm{C} / 1$ min e extensão a $65^{\circ} \mathrm{C} / 8 \mathrm{~min}$. Após a amplificação, os fragmentos foram separados por eletroforese em agarose a 1,2\% com tampão 0,5 XTBE (pH 8,0) e corrida a $20 \mathrm{~V} / 15 \mathrm{~h}$. O gel foi corado com brometo de etídio ( $5 \mathrm{mg} / \mathrm{L})$, visualizado em luz UV e posteriormente fotografado para documentaçao.

A massa molecular dos fragmentos foi calculada utilizando-se o software "Quantity One" (Bio Rad) (SILVA e MARTINS, 2006). Com base no número e tamanho dos fragmentos foram estabelecidos os perfis de ERIC-PCR. Variações na intensidade do fragmento não foram consideradas como fragmentos diferentes.

A construção do dendrograma foi efetuada a partir da introdução da matriz com os números equivalentes aos fragmentos de cada perfil no programa NTSYS-PC 2.10 (ROHLF, 2000), usandose o coeficiente de pareamento simples.

\subsection{ANÁLISE ESTATÍSTICA}

Calculou-se o índice de discriminação (ID) da técnica de acordo com o índice de diversidade de Simpson, conforme descrito por Hunter e Gaston (1998).

As relações genéticas e as divergências entre os perfis foram calculadas a partir de matriz de distância genética, definida com base na semelhança entre os diferentes "fingerprints" e representada em dendrograma construído com o método de análise "Neighbor-joining algoritm" (KUMAR et al., 1996).

Os dados obtidos nos diferentes perfis do total de cepas, bem como em cada origem foram submetidos à análise de variância (ANOVA "two-way") e ao teste t de Student bi-caudal, seguindo metodologia proposta por Costa Neto (1992).

\section{RESULTADOS}

\subsection{PERFIS DE ERIC-PCR EM E. coli}

Para melhor caracterização, os perfis foram identificados com a letra $\mathrm{P}$ seguida do número. Assim sendo, a Tabela 1 apresenta a distribuição dos perfis de ERIC-PCR de E. coli isoladas da 
superfície de meias-carcaças bovinas. Pode-se observar que as 90 amostras analisadas distribuíramse em 32 perfis, tendo sido verificadas duas não tipáveis (NT). No total da amostragem foram obtidas frequências de ocorrência que variaram de $1,11 \%$ a $12,22 \%$ nos diferentes perfis. Assim, os perfis P1 e P2 foram apresentados por 11/90 (12,22\%) amostras cada, P9 em 03/90 (3,33\%), P10 e P11 em 02/90 (2,22\%) cada, P5 e P6 em 05/90 (5,55\%) cada e os perfis P23, P27 e P36 em 01/90 $(1,11 \%)$ cada.

\section{TABELA 1 - DISTRIBUIÇÃO DOS PERFIS DE ERIC-PCR EM E. coli ISOLADAS DE SUPERFÍCIE DE MEIAS-CARCAÇAS BOVINAS DE DOIS MATADOUROS-FRIGORÍFICOS - GOIÂNIA/2008}

\begin{tabular}{|c|c|c|}
\hline PERFIS DE ERIC-PCR & $\mathrm{N}$ & $\%$ \\
\hline \multicolumn{3}{|c|}{ MEIAS-CARCAÇAS RESFRIADAS } \\
\hline $\mathrm{P} 1$ & $11 / 90^{1}$ & 12,22 \\
\hline P2 & $11 / 90$ & 12,22 \\
\hline P18 & $01 / 90$ & 1,11 \\
\hline P19 & $01 / 90$ & 1,11 \\
\hline P9 & $03 / 90$ & 3,33 \\
\hline P10 & $02 / 90$ & 2,22 \\
\hline P11 & $02 / 90$ & 2,22 \\
\hline P5 & $05 / 90$ & 5,55 \\
\hline P21 & $01 / 90$ & 1,11 \\
\hline P22 & $01 / 90$ & 1,11 \\
\hline P12 & $02 / 90$ & 2,22 \\
\hline P13 & $02 / 90$ & 2,22 \\
\hline P23 & $01 / 90$ & 1,11 \\
\hline $\mathrm{P} 14$ & $02 / 90$ & 2,22 \\
\hline P25 & $01 / 90$ & 1,11 \\
\hline P6 & $05 / 90$ & 5,55 \\
\hline P27 & $01 / 90$ & 1,11 \\
\hline P15 & $02 / 90$ & 2,22 \\
\hline P32 & $01 / 90$ & 1,11 \\
\hline P33 & $01 / 90$ & 1,11 \\
\hline P36 & $01 / 90$ & 1,11 \\
\hline $\mathrm{P} 7$ & $04 / 90$ & 4,44 \\
\hline \multicolumn{3}{|c|}{ MEIAS-CARCAÇAS QUENTES } \\
\hline P8 & $03 / 90$ & 3,33 \\
\hline P3 & $08 / 90$ & 8,88 \\
\hline P16 & $02 / 90$ & 2,22 \\
\hline P4 & 07/90 & 7,77 \\
\hline P26 & $01 / 90$ & 1,11 \\
\hline P30 & $01 / 90$ & 1,11 \\
\hline P35 & $01 / 90$ & 1,11 \\
\hline P38 & $01 / 90$ & 1,11 \\
\hline P17 & $02 / 90$ & 2,22 \\
\hline P39 & $01 / 90$ & 1,11 \\
\hline NT & $02 / 90$ & 2,22 \\
\hline
\end{tabular}

${ }^{1}$ Número de cepas pertencentes ao perfil sobre o total de cepas analisadas. 
Na Tabela 2 podem ser verificados os perfis de ERIC-PCR obtidos no total de amostras de E. coli isoladas da superfície de meias-carcaças quentes e resfriadas de cada matadouro-frigorífico. As isoladas de superfícies de meias-carcaças dos matadouros-frigoríficos A e B distribuíram-se em 16 perfis.

TABELA 2 - DISTRIBUIÇÃO DOS PERFIS DE ERIC-PCR EM E. coli ISOLADAS DA SUPERFÍCIE DE MEIAS-CARCAÇAS QUENTES E RESFRIADAS, SEGUNDO OS MATADOUROS-FRIGORÍFICOS A E B - GOIÂNIA/2008

\begin{tabular}{|c|c|c|c|c|}
\hline PERFIL & $\mathbf{N}$ & $\%$ & $\mathrm{~N}^{*}$ & \%* \\
\hline MATADOURO-FRIGORÍFICO A & & & \multicolumn{2}{|c|}{ TOTAL } \\
\hline \multicolumn{5}{|l|}{ MEIAS-CARCAÇAS QUENTES } \\
\hline P4 & 07/09 & 77,78 & $07 / 55$ & 12,72 \\
\hline P26 & $01 / 09$ & 11,11 & $01 / 55$ & 1,81 \\
\hline P39 & $01 / 09$ & 11,11 & $01 / 55$ & 1,81 \\
\hline \multicolumn{5}{|l|}{ MEIAS-CARCAÇAS RESFRIADAS } \\
\hline $\mathrm{P} 1$ & $11 / 46$ & 23,91 & $11 / 55$ & 20,0 \\
\hline $\mathrm{P} 2$ & $11 / 46$ & 23,91 & $11 / 55$ & 20,0 \\
\hline P9 & $03 / 46$ & 6,52 & $03 / 55$ & 5,45 \\
\hline P10 & $02 / 46$ & 4,35 & $02 / 55$ & 3,63 \\
\hline P11 & $02 / 46$ & 4,35 & $02 / 55$ & 3,63 \\
\hline P5 & $05 / 46$ & 10,87 & $05 / 55$ & 9,09 \\
\hline P23 & $01 / 46$ & 2,17 & $01 / 55$ & 1,81 \\
\hline P14 & $02 / 46$ & 4,35 & $02 / 55$ & 3,63 \\
\hline P25 & $01 / 46$ & 2,17 & $01 / 55$ & 1,81 \\
\hline P6 & $05 / 46$ & 10,87 & $05 / 55$ & 9,09 \\
\hline P27 & $01 / 46$ & 2,17 & $01 / 55$ & 1,81 \\
\hline P33 & $01 / 46$ & 2,17 & $01 / 55$ & 1,81 \\
\hline P36 & $01 / 46$ & 2,17 & $01 / 55$ & 1,81 \\
\hline \multicolumn{3}{|l|}{ MATADOURO-FRIGORÍFICO B } & \multicolumn{2}{|c|}{ TOTAL } \\
\hline \multicolumn{5}{|l|}{ MEIAS-CARCAÇAS QUENTES } \\
\hline P8 & $03 / 20^{* *}$ & 15,00 & $03 / 35^{* *}$ & 8,57 \\
\hline P3 & $08 / 20$ & 40,00 & $08 / 35$ & 22,85 \\
\hline P16 & $02 / 20$ & 10,00 & $02 / 35$ & 5,71 \\
\hline P30 & $01 / 20$ & 5,00 & $01 / 35$ & 2,85 \\
\hline P35 & $01 / 20$ & 5,00 & $01 / 35$ & 2,85 \\
\hline P38 & $01 / 20$ & 5,00 & $01 / 35$ & 2,85 \\
\hline P17 & $02 / 20$ & 15,00 & $02 / 35$ & 5,71 \\
\hline \multicolumn{5}{|l|}{ MEIAS-CARCAÇAS RESFRIADAS } \\
\hline $\mathrm{P} 18$ & $01 / 15$ & 6,67 & $01 / 35$ & 2,85 \\
\hline P19 & $01 / 15$ & 6,67 & $01 / 35$ & 2,85 \\
\hline P21 & $01 / 15$ & 6,67 & $01 / 35$ & 2,85 \\
\hline P22 & $01 / 15$ & 6,67 & $01 / 35$ & 2,85 \\
\hline P12 & $02 / 15$ & 13,33 & $02 / 35$ & 5,71 \\
\hline P13 & $02 / 15$ & 13,33 & $02 / 35$ & 5,71 \\
\hline P15 & $02 / 15$ & 13,33 & $02 / 35$ & 5,71 \\
\hline P32 & $01 / 15$ & 6,67 & $01 / 35$ & 2,85 \\
\hline $\mathrm{P} 7$ & $04 / 15$ & 26.67 & $04 / 35$ & 11,42 \\
\hline
\end{tabular}

*Relação às amostras totais em determinado Frigorífico.

${ }^{\star *}$ Consideram-se 2 amostras NT (não tipáveis) no total de isolados de meias-carcaças quentes. 


\subsection{PERFIS DE ERIC-PCR EM E. coli O157:H7}

Os perfis de $E$. coli $\mathrm{O} 157: \mathrm{H} 7$ foram identificados com as letras $\mathrm{PP}$ seguidas do número. $\mathrm{Na}$ Tabela 3 podem ser verificados os perfis de ERIC-PCR em E. coli O157:H7 no total analisado e nas amostras isoladas da superfície de meias-carcaças dos dois matadouros-frigoríficos. Foram obtidos quatro perfis de E. coli $\mathrm{O} 157: \mathrm{H} 7$ nas meias-carcaças quentes e resfriadas, ressaltando-se que cinco não tipáveis foram verificadas nessas últimas.

No total de amostras isoladas de superfícies de meias-carcaças do matadouro-frigorífico $\mathrm{A}$ (Tabela 3), as 15 cepas analisadas distribuíram-se em seis perfis com percentuais variando de $6,67 \%$ a 40,02\%. Verificou-se predomínio do perfil PP1, apresentado por 06/15 $(40,02 \%)$ amostras e menor ocorrência de PP3 (02/12 - 16,67\%) e PP4 (01/12 - 8,33\%). Nas amostras resfriadas, os perfis PP1, PP3 e PP4 foram exibidos por 06/12 (50\%), 02/12 (16,67\%) e 01/12 (8,33\%), respectivamente.

\section{TABELA 3 - DISTRIBUIÇÃO DOS PERFIS DE ERIC-PCR EM E. coli 0157:H7 ISOLADAS DA SUPERFÍCIE DE MEIAS-CARCAÇAS BOVINAS - GOIÂNIA/2008}

\begin{tabular}{rcccc}
\hline PERFIL & N & $\%$ & $\mathrm{~N}^{*}$ & $\%^{*}$ \\
\hline MATADOURO-FRIGORÍFICO A & & & \multicolumn{3}{c}{ TOTAL } \\
\hline MEIAS-CARCAÇAS QUENTES & & & & \\
PP6 & $01 / 03$ & 33,33 & $1 / 15$ & 6,67 \\
PP7 & $01 / 03$ & 33,33 & $1 / 15$ & 6,67 \\
PP8 & $01 / 03$ & 33,33 & $1 / 15$ & 6,67 \\
MEIAS-CARCAÇAS RESFRIADAS & & & & \\
PP1 & $06 / 12^{* *}$ & 50,00 & $06 / 15$ & 40,02 \\
PP3 & $02 / 12$ & 16,67 & $02 / 15$ & 13,34 \\
PP4 & $01 / 12$ & 8,33 & $01 / 15$ & 6,67 \\
\hline MATADOURO-FRIGORÍFICO B & & & & TOTAL \\
\hline MEIAS-CARCAÇAS QUENTES & & & & \\
PP5 & $01 / 01$ & 100.00 & $01 / 06$ & 16,67 \\
MEIAS-CARCAÇAS RESFRIADAS & & & & \\
PP2 & $03 / 05^{* * *}$ & 60,00 & $03 / 06$ & 50,00 \\
\hline
\end{tabular}

${ }^{*}$ Relação às amostras totais em determinado Frigorífico.

${ }^{* *}$ Consideram-se 3 amostras NT (não tipáveis) no total de isolados de meias-carcaças resfriadas.

${ }^{* * *}$ Consideram-se 2 amostras NT (não tipáveis) no total de isolados de meias-carcaças resfriadas.

Quanto ao total de amostras de E. coli O157:H7 isoladas de superfícies de meias-carcaças do matadouro-frigorífico $\mathrm{B}$, as seis analisadas distribuíram-se nos perfis PP2 e PP5, com predomínio do primeiro, apresentado por 03/06 (60\%) amostras, sendo as demais não tipáveis. Já o perfil PP5 foi exibido por 01/06 (16,67\%) amostra.

\subsection{RELAÇÕES GENÉTICAS ENTRE AS AMOSTRAS DE E. coli e E. coli O157:H7}

Visando estabelecer as relações genéticas existentes entre as amostras foi utilizado o coeficiente de pareamento simples para a análise dos dados, tendo sido construído dendrograma de similaridade (Figura 1) a partir dos 40 perfis gerados pelas amostras de E. coli e E. coli O157:H7 isoladas de 20 meias-carcaças quentes e resfriadas dos matadouros-frigoríficos A e B.

A similaridade entre os 40 perfis de E. coli e E. coli $\mathrm{O} 157: \mathrm{H} 7$ variou de $73,60 \%$ a $97,70 \%$. Os perfis foram divididos em dois grupos, GI e GII, com similaridade acima de 73,60\%. O Grupo GIl continha apenas um perfil P22, representado por cinco cepas de $E$. coli isoladas de meiascarcaças resfriadas do matadouro-frigorífico A. O grupo $\mathrm{Gl}$ foi divido em dois subgrupos, Gl.1 e 
GI.2, com similaridade de 75,60\%, no qual o Gl.2 foi representado apenas pelo perfil P40, com o total de quatro cepas de $E$. coli isoladas de meias-carcaças resfriadas do matadouro-frigorífico $B$. O subgrupo GI.1 foi dividido em três "clusters", A, B e C, com similaridade de 77,30\% para os dois primeiros e de $76,80 \%$ para o C. O "cluster" C foi dividido em "subcluster", representado pelos perfis P30, P31, P215 e P33 com similaridade de 84,30\%. Esses perfis correspondem a meias-carcaças quentes e resfriadas do matadouro-frigorífico A. O "cluster" B também foi dividido por "subcluster" com similaridade de $85,50 \%$, representado pelos perfis $\mathrm{P} 10, \mathrm{P} 11$ e P5 com total de nove cepas, todas isoladas de meias-carcaças resfriadas do matadouro-frigorífico $A$.

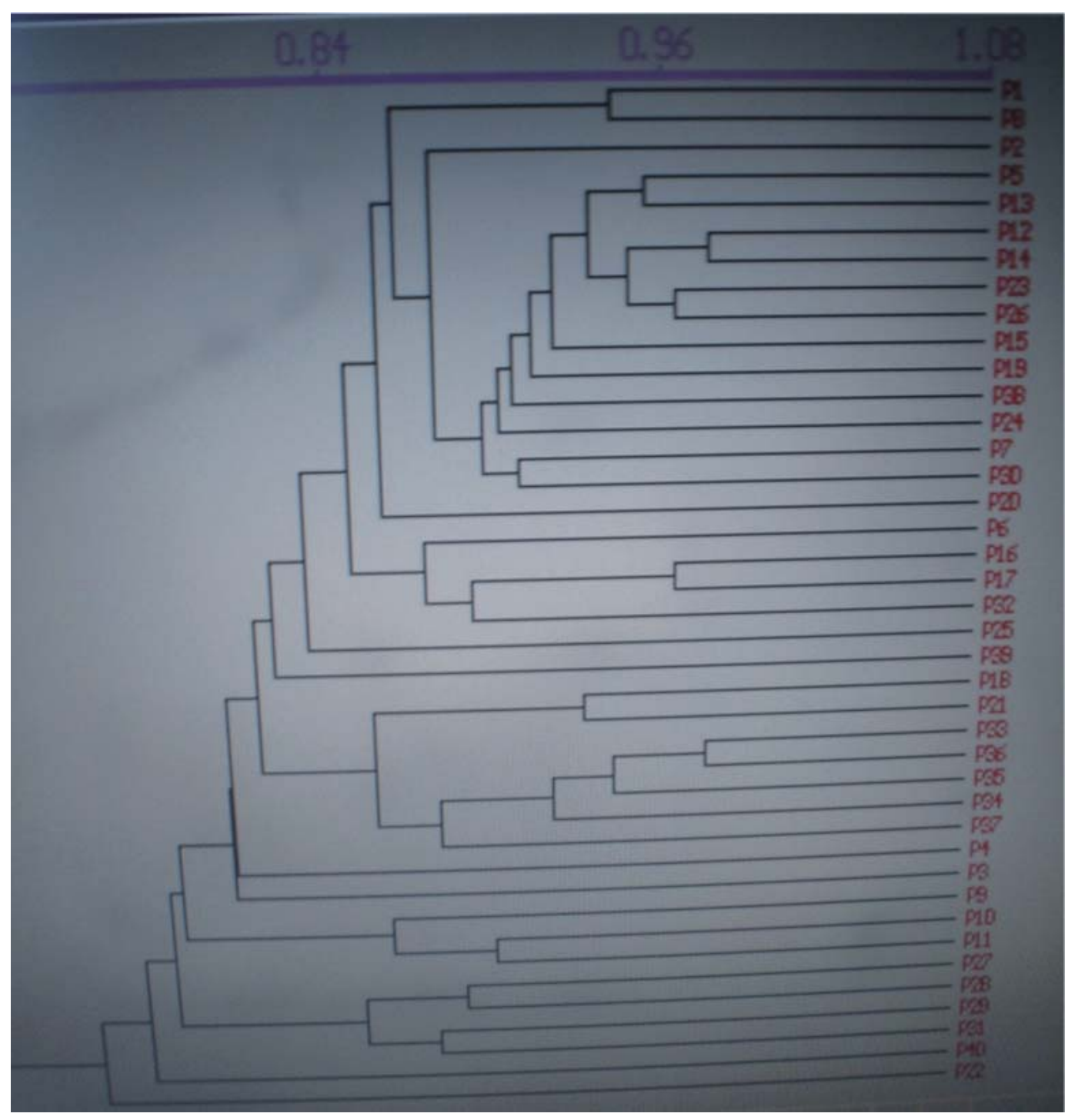

FIGURA 1 - DENDROGRAMA OBTIDO PELA TÉCNICA DE ERIC-PCR EM CEPAS DE E. coli e E. coli 0157:H7 ISOLADAS DE MEIAS-CARCAÇAS QUENTES E RESFRIADAS DOS MATADOUROS-FRIGORÍFICOS A e B - GOIÂNIA/2008

As amostras que formam os perfis agrupados em GI, GII, GI.2, GI.1 e os "clusters" B e C representam apenas $27,93 \%$ do total de amostras. O restante, $72,07 \%$ foi agrupado no "cluster" que engloba um clone. O "cluster" A foi dividido em três "subclusters" A1, A2 e A3 com similaridade de $80,80 \%$, sendo que os dois últimos foram representados por um perfil cada, P18 e $\mathrm{P} 2$, respectivamente. $\mathrm{O}$ "subcluster" A1 foi subdividido em dois novos agrupamentos, A1.1 e A1.2, com similaridade de $81,50 \%$. 
Quando analisados apenas os perfis gerados pelas amostras de E. coli $\mathrm{O} 157: \mathrm{H} 7$ isoladas de meias-carcaças quentes e resfriadas dos matadouros-frigorificos $A$ e $B$ verificam-se as relações genéticas existentes entre as mesmas (Figura 2). Nesse dendrograma de similaridade também foi utilizado o coeficiente de pareamento simples para a análise dos dados.

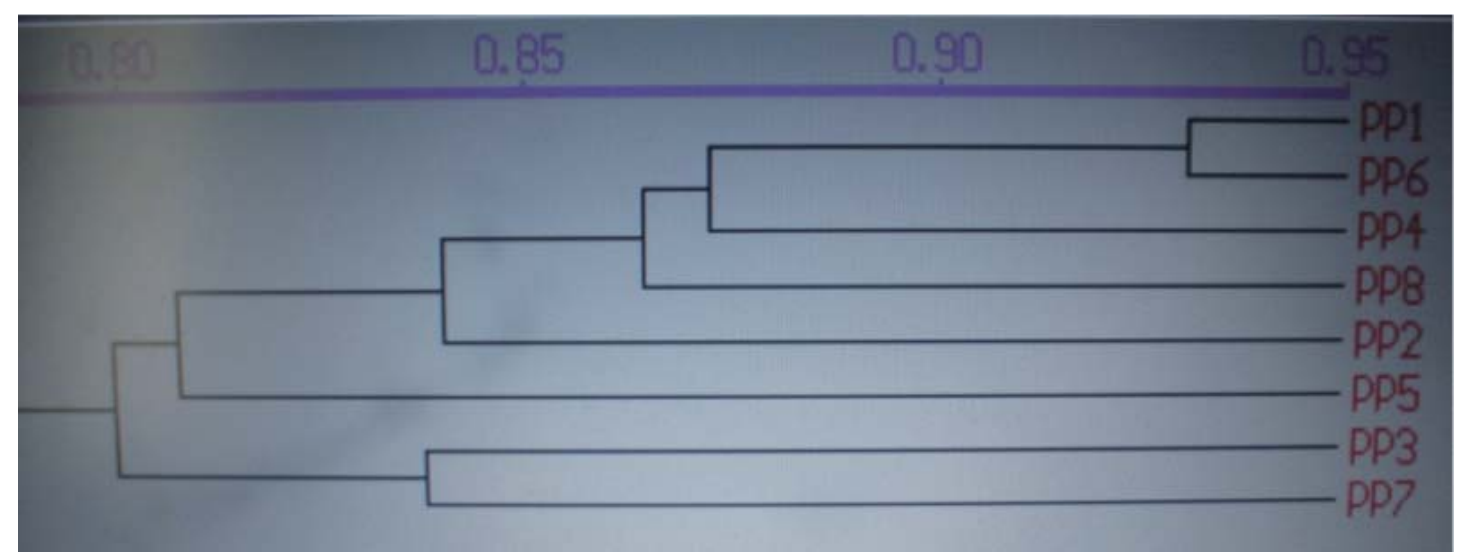

FIGURA 2 - DENDROGRAMA OBTIDO PELA TÉCNICA DE ERIC-PCR EM CEPAS DE E. coli 0157:H7 ISOLADAS DE MEIAS-CARCAÇAS QUENTES E RESFRIADAS DOS MATADOUROS-FRIGORÍFICOS A E B - GOIÂNIA/2008

A similaridade entre os sete perfis de E. coli $\mathrm{O} 157: \mathrm{H} 7$ variou de $78,00 \%$ a $93,00 \%$. Os perfis foram divididos em dois grupos, GRI e GRII, com similaridade de $79,80 \%$. O Grupo GRII foi representado pelos perfis P28 e P31, identificados por cepas de E. coli O157:H7 isoladas de meias-carcaças resfriadas e quentes do matadouro-frigorífico $A$, respectivamente. A similaridade entre esses perfis foi de $83,70 \%$.

O grupo GRI foi divido em dois subgrupos, GRI.1 e GRI.2, com similaridade de 80,70\%. O subgupo GRI.1 foi representado apenas pelo perfil PP5, identificado em uma meia-carcaça quente do matadouro-frigorífico B. O subgrupo GRI.2 foi dividido em dois "clusters", GR.a e GR.b, com similaridade de $84,00 \%$. O GR.b foi representado apenas pelo perfil PP2, com total de três cepas de E. coli O157:H7 isoladas de meias-carcaças resfriadas do matadouro-frigorífico B. O "cluster" GR.a foi dividido em dois "subclusters", C e D, com similaridade de $86,40 \%$ para o C, representado apenas pelo perfil PP8 e de $87,20 \%$ para o D. O "cluster" D foi novamente dividido em agrupamento, representado pelos perfis PP1 e PP6, com similaridade de 93,00\%. Esses perfis correspondem a meias-carcaças resfriadas e quentes do matadouro-frigorífico $B$, respectivamente.

\section{DISCUSSÃo}

\subsection{PERFIS DE ERIC-PCR EM E. coli}

A discriminação obtida com a técnica de ERIC-PCR foi bastante satisfatória no total analisado de E. coli e E. coli O157:H7, independente do sorovar, com Índice de Discriminação (ID) de 0,959 . No entanto, não foi possível caracterizar a totalidade da amostragem por essa técnica, pois elevado percentual $(23,81 \%)$ das 101 amostras não puderam ser tipadas.

A técnica de ERIC-PCR para as amostras de E. coli apresentou ID de 0,948, indicando a elevada capacidade de discriminação da técnica para a espécie analisada. Já o ID apenas de E. coli $0157: \mathrm{H} 7$ foi de 0,841 , indicando menor eficiência para caracterização desse sorovar na amostragem analisada.

O ID obtido para o matadouro-frigorífico A, independente do sorovar, foi de 0,921 . Esse índice passou a 0,894 com os resultados do ERIC para E. coli e para 0,757 quando E. coli $\mathrm{O} 157: \mathrm{H} 7$ foi considerada isoladamente. No matadouro-frigorífico $\mathrm{B}$, o ID para E. coli $\mathrm{O} 157: \mathrm{H} 7$ foi de $0,5 \mathrm{em}$ razão de poucas cepas serem positivas para $E$. coli 0157:H7 e cinco delas não serem tipáveis. Além disso, as 16 cepas tipadas foram distribuídas em apenas oito perfis.

Os resultados obtidos no presente estudo concordam com os de Mohapatra et al. (2007), que 
verificaram alta capacidade de discriminação dos métodos de caracterização molecular utilizados, como ERIC, BOX e REP-PCR na determinação e identificação de $E$. coli isoladas de fezes humanas e de animais domésticos e selvagens no Canadá. Também são corroborados pelos resultados de Moura, Irino e Vidotto (2001) que constataram elevada capacidade de discriminação das técnicas de ERIC e REP-PCR. Esses autores verificaram extensa diversidade genética em cepas de E. coli, porém em E. coli aviária.

Na discriminação de Salmonella, a técnica de ERIC-PCR foi utilizada com sucesso por Van Lith e Aarts (1994) e por Milleman et al. (1996), porém Burr, Josephson e Pepper (1998) não conseguiram diferenciação dos sorotipos utilizando os mesmos "primers".

Os perfis obtidos mostraram-se exclusivos de cada fonte. No matadouro-frigorífico A, 16 perfis foram obtidos de ERIC-PCR de E. coli para o total de 51 cepas analisadas. No matadourofrigorífico B, 17 perfis foram obtidos do total de 39 cepas. Também foram encontrados diferentes perfis de $E$. coli isoladas da mesma meia-carcaça.

Em estudo realizado por Mohapatra et al. (2007) foram formados dois "clusters", permitindo diferenciar as cepas de $E$. coli de fezes humanas das cepas isoladas de animais. Já no presente estudo foram formados três "clusters", mas não completamente separados em cepas do mesmo matadouro-frigorífico ou diferenciados em cepas isoladas de meias-carcaças quentes ou resfriadas. Foram observados também vários agrupamentos diferentes formados entre as cepas de E. coli O157:H7

Dombek et al. (2000) utilizaram as técnicas de REP e BOX-PCR para caracterização molecular de 208 cepas de $E$. coli isoladas de fezes humanas e de animais. Obtiveram perfis em 125 isolados de E. coli, sendo que as cepas de fonte humana agruparam-se em quatro "clusters" que, no entanto, também incluíram duas cepas de aves aquáticas. Os outros isolados de fonte animal foram agrupados em quatro "clusters" diferentes. O índice de discriminação das técnicas utilizadas para diferenciar cepas de $E$. coli de fonte humana, de vacas, de ovelhas, de patos e de gansos foi de $93,8 \%$, também inferior ao obtido no presente trabalho.

A técnica de ERIC-PCR foi utilizada para caracterização epidemiológica de 40 cepas enterotoxigênicas de $E$. coli isoladas de suínos com diarréia e 13 cepas isoladas do ambiente de criatórios suínos por COSTA et al. (2006). As amostras foram separadas em "clusters", porém não relacionados aos fatores de virulência da bactéria e não foi demonstrado o poder discriminatório esperado da técnica de ERIC-PCR pelos autores, contrastando com os resultados aqui descritos.

\subsection{PERFIS ERIC-PCR DE E. coli O157:H7}

Foram obtidos oito perfis de ERIC-PCR de E. coli O157:H7 isoladas de meias-carcaças quentes e resfriadas dos matadouros-frigoríficos $A$ e $B$. O índice de discriminação entre essas cepas foi de 0,841 , mostrando-se menor que o obtido para $E$. coli provavelmente em função do reduzido número de cepas de $E$. coli O157:H7 avaliadas e de terem sido analisadas várias cepas isoladas da mesma amostra.

Osek (2002) utilizou a técnica de BOX-PCR para relacionar geneticamente cepas E. coli O157:H7 isoladas de suínos. A metodologia foi sensível o bastante para revelar diferenças genéticas entre E. coli O157:H7 de origem suína, apresentando-se como ferramenta rápida e conveniente para diferenciação de E. coli do mesmo sorogrupo.

\subsection{RELAÇÕES GENÉTICAS}

Neste estudo, o número de fragmentos formados pela técnica de ERIC-PCR para E. coli e E. coli O157:H7 variou de um a dezoito.

Pela técnica de ERIC-PCR, Mohapatra, Broersma e Mazumder (2008) obtiveram perfis com 4 a 13 fragmentos de $E$. coli isoladas de amostras de fezes de aves, enquanto que pelas técnicas de REP-PCR e BOX-PCR foram formados perfis com seis a 18 fragmentos. Já pela técnica de (GTG) foram obtidos de dez a 25 fragmentos.

Em estudo realizado por Nikam (2004), os perfis de REP-PCR de E. coli isoladas de aves apresentaram de um a 13 fragmentos, tendo sido verificado 100\% de polimorfismo entre as cepas analisadas. Não foram observados fragmentos comuns entre os perfis obtidos. Pela técnica de BOX-PCR, os perfis variavam de um a 11 fragmentos e o polimorfismo foi de $100 \%$. Já por ERICPCR foram obtidos perfis com dois a 13 fragmentos, verificando-se também $100 \%$ de polimorfismo. 
Esses resultados mostram a intensa heterogeneidade, ou diversidade genética das cepas $E$. coli isoladas de aves.

Ling et al. (2000) observaram a heterogeneidade genética de cepas de E. coli O157:H7 isoladas de hamburguer de frango e bovino. As cepas foram caracterizadas por ERIC-PCR e cada uma das 30 amostras analisadas apresentou perfil genético único, cujas bandas eram diferentes em cada perfil, mostrando polimorfismo entre os modelos estudados.

No presente estudo foi constatada a presença de determinados fragmentos em muitos perfis, diferenciando-se dos estudos realizados por Nikam (2004) e Ling et al. (2000). Porém não foi verificada a presença constante de um fragmento em todos os perfis obtidos como observado por Giammanco et al. (2002). Esses constataram três principais fragmentos e dois menores de massa molecular entre 200 bp e 1300 bp em todos os perfis de E. coli O157:H7 obtidos, independentemente da origem das cepas. A presença constante de um fragmento em todos os perfis obtidos torna a técnica de PFGE inapropriada para distinguir epidemiologicamente cepas de E. coli O157:H7 não relacionadas entre si.

Giammanco et al. (2002) estudaram 57 cepas de E. coli O157:H7 de "swabs" coletados do reto de bovinos e isoladas de casos de pessoas com síndrome urêmico-hemolítica e diarréia. A relação genética entre essas cepas foi estudada pela técnica de PFGE. Foram obtidos 54 perfis que apresentavam de 13 a 22 bandas e se agruparam em quatro "clusters", evidenciando alto poder de discriminação. Essa técnica também possibilitou a demonstração da transmissão horizontal de uma única cepa de E. coli O157:H7 isolada de duas fazendas, assim como a caracterização de isolados relacionados a surtos alimentares.

Johnson et al. (1995) utilizaram a técnica de PFGE para a investigação de surto de $E$. coli O157:H7 veiculado por carne bovina. As cepas isoladas de pacientes resultaram no mesmo perfil das cepas isoladas da carne analisada, dividido em 20 fragmentos, comprovando a relação genética entre as cepas de E. coli O157:H7 isoladas de pacientes e dos alimentos implicados no surto.

Neste estudo não foi verificada a transmissão horizontal de uma única cepa de $E$. coli O157: $\mathrm{H} 7$, tendo em vista que os oito perfis obtidos de E. coli O157:H7 foram distribuídos entre cepas encontradas apenas nas meias-carcaças das quais foram isoladas.

Analisando os perfis de ERIC-PCR em E. coli aviária, Moura et al. (2001) verificaram que esses variavam de oito a 17 fragmentos e obtiveram pela técnica de REP-PCR perfis com seis a 20 fragmentos. As amostras foram agrupadas em quatro "clusters" principais, cada um com $60 \%$ de similaridade, tanto por ERIC-PCR quanto por REP-PCR, correspondendo a cepas com diferentes graus de patogenicidade. Entretanto, 28/50 (56\%) das cepas patogênicas foram agrupadas em dois grupos externos a três "clusters" principais e $86 \%$ das cepas não patogênicas foram agrupadas em um "cluster" e um subgrupo. Os 32 sorotipos detectados foram distribuídos em todos os "clusters" com diferentes perfis genéticos, entretanto cepas do mesmo sorotipo tenderam a formar "clusters" com similaridade maior que $80 \%$.

Os 40 perfis de E. coli e E. coli O157:H7 observados no presente trabalho distribuíramse entre os agrupamentos formados, mas a maioria ficou no "cluster" A. E. coli O157:H7, o único sorotipo conhecido, ficou distribuído em oito perfis, dos quais sete agruparam-se no "cluster" $A$.

A grande diversidade genética observada em $E$. coli isoladas da superfície da mesma meia-carcaça ou da mesma amostra sugere contaminação com origem em múltiplas fontes, ou coexistência de diferentes sorovares na mesma amostra, já que se conhece apenas o sorovar O157:H7. A grande diversidade genética poderia ainda ser explicada devido às muitas fontes de contaminação no matadouro-frigorífico, como pele do animal, manipuladores, utensílios, equipamentos e contaminação cruzada por meia-carcaça.

\section{CONCLUSÃO}

No matadouro-frigorífico A foi encontrada maior variedade de perfis, tanto de $E$. coli quanto de $E$. coli O157:H7, que no matadouro-frigorífico B.

Elevada heterogeneidade genética foi observada, tanto em $E$. coli quanto em $E$. coli O157:H7, embora a maioria analisada tenha se agrupado num "cluster" principal.

Os perfis de E. coli O157:H7 mostraram-se exclusivos a esse sorovar e também foram específicos de cada fonte.

Verificou-se elevada ocorrência de cepas não tipáveis de E. coli e E. coli O157:H7, isoladas da superfície de meias-carcaças quentes e resfriadas dos dois matadouros-frigoríficos. 


\section{ABSTRACT \\ PERFILS DETECTION BY ERIC-PCR OF Escherichia coli AND E. coli 0157:H7 ISOLATED ON BOVINE CARCASS}

The present study aimed to characterize by ERIC-PCR E. coli and E. coli O157:H7 isolated from bovine carcass surfaces (with and without refrigeration) from two different slaughterhouse/abattoir at Goias State (Brazil), and verify the ability of this methodology to identify different isolates of E. coli and E. coli O157:H7. ERIC-PCR technique was used for the molecular characterization of 111 samples, and it were obtained 32 fingerprints separated in 90 isolates of $E$. coli and eight fingerprints separated in 16 isolates of $E$. coli $\mathrm{O} 157: \mathrm{H} 7$. From the total sample, two isolates of $E$. coli and five of $E$. coli O157:H7 were non-typable. The fingerprints varied from one to 18 bands. ERIC-PCR presented high discriminatory index between E. coli and E. coli O157:H7 (0.96).

KEY-WORDS: MOLECULAR CHARACTERIZATION; MEAT; PATHOGENIC E. coli.

\section{REFERÊNCIAS}

1 AUSUBEL, F. M.; BRENT, R.; KINGSTON, R. E.; MOORE, D. D.; SEIDMAN, J. G.; SMITH, J. A.; STRUHL, K. Current protocols in biology: molecular biology. New York: John Wiley \& Sons, 1994. 459 p.

2 BURR, M.D.; JOSEPHSON, K.L.; PEPPER, I.L. An evaluation of ERIC PCR and AP PCR fingerprinting for discriminating Salmonella serotypes. Letters in Applied Microbiology, v.27, p.24-30, 1998.

3 CHANSIRIPORNCHAI, N.; RAMASOOTA, P.; SASIPREYAJAN, J.; SVENSON, S.B. Differentiation of avian Escherichia coli (APEC) isolates by random amplified polymorphic DNA (RAPD) analysis. Veterinary Microbiology, v.80, n.1, p.7580, 2001.

4 COSTA, M.M.; SILVA, M.S.; SPRICIGO, D.A.; WITT, N.M.; MARCHIORO, S.B.; KOLLING, L.; VARGAS, A.P.C. Caracterização epidemiológica, molecular e perfil de resistência aos antimicrobianos de Escherichia coli isoladas de criatórios suínos do sul do Brasil. Pesquisa Veterinária Brasileira, v.26, n.1, p.5-8, 2006.

5 COSTA NETO, P.L.O. Estatística. 12. ed. São Paulo: Edgard Blücher, 1992. 264 p.

6 DOMBEK, P. E.; JOHNSON, L. K.; ZIMMERLEY, S. T.; SADOWISKY, M. J. Use of repetitive DNA sequences and the PCR to differentiate Escherichia coli isolates from human and animal sources. Applied of Environmental Microbiology, v. 66, n. 6, p.2572-2577, 2000 .

7 DUCHAUD, E.; RUSNIOK, C.; FRANGEUL, L. The genome sequence of the entomopathogenic bacterium Photorhabdus luminescens. National Biotechnology, v. 21, n.11, p.1307-1311, 2003.

8 GIAMMANCO, G.M.; PIGNATO, S.; GRIMONT, F.; GRIMONT, P.A.D.; CAPRIOLI, A.; MORABITO, S.; GIAMMANCO, G. Characterization of Shiga toxin-producing Escherichia coli $\mathrm{O} 157: \mathrm{H} 7$ isolated in Italy and in France. Journal of Clinical Microbiology, v.40, p.4619-4624, 2002.

9 HULTON, C.S.J.; HIGGINS, C.F.; SHARP, P.M. ERIC sequences: a novel family of repetitive elements in the genomes of Escherichia coli, Salmonella typhimurium and other enterobacteria. Molecular Microbiology, v.5, p.825-834, 1991.

10 HUNTER, P.R.; GASTON, M.A. Numerical index of the discriminatory ability of typing systems: an application of simpson's index of diversity. Journal of Clinical Microbiology, v.21, n.11, p.2465-2466,1998.

11 JOHNSON, J.M.; WEAGANT, S.D.; JINNEMAN, K.C.; BRYANT, J.L. Use of Pulsed-Field Gel Electrophoresis for epidemiological study of Escherichia coli O157:H7 during a food-bourne outbreak. Applied and Environmental Microbiology, v.61, n.10, p. 2806-2808, 1995.

12 KUMAR, S. et al. A stepwise algorithm for finding minimum evolution trees. Molecular Biology Evolution, v. 13, p.584593, 1996.

13 LING, O.W.; RADU, S.; RUSUL, G.; PURWATI, E.; LIHAN, S. Enterobacterial repetitive intragenic consensus (ERIC) genotyping of Escherichia coli O157:H7. Pakistan Journal of Biological Sciences, v.3, p.35-37, 2000.

14 MARTIN, B.; HUMBERT, O.; CAMARA, M.; GUENZI, E.; WALKER, J.; MITCHEL, T.; ANDREW, P.; PRUDHOMME, M.; ALLOING, G.; HAKENBECK, R.; MORRISON, D.A.; BOULNOIS, G.J.; CLAVERYS, J.P. A highly conserved repeated DNA element located in the chromosome of Streptococcus pneumoniae. Nucleic Acids Research, v. 20, p.3479-3483, 1992.

15 MILLEMANN, Y.; LESAGE-DESCAUSES, M.C.; LAFONT, J.P.; CHASLUS-DANCLA, E. Comparison of random amplified polymorphic DNA analysis and enterobacterial repetitive intergenic consensus-PCR for epidemiological studies of Salmonella. FEMS Immunology and Medical Microbiology, v.14, p.129-134, 1996. 
16 MOHAPATRA, B.R.; BROERSMA, K.; MAZUMDER, A. Differentiation of fecal Escherichia coli from poultry and free-living birds by (GTG) ${ }_{5}$-PCR genomic fingerprinting. International Journal of Medical Microbiology, v. 298, p.245-252, 2008.

17 MOHAPATRA, B.R.; BROERSMA, K.; NORDIN, R.; MAZUMDER, A. Evaluation of Repetitive Extragenic PalindromicPCR for discrimination of fecal Escherichia coli from humans, and different domestic- and wild-animals. Microbiology and Immunology, v.51, p.733-740, 2007.

18 MOURA, A.C.; IRINO, K.; VIDOTTO, M.C. Genetic variability of avian Escherichia coli strains evaluated by Enterobacterial Repetitive Intergenic Consensus and Repetitive Extragenic Palindromic Polymerase Chain Reaction. Avian Diseases, v.45, n.1,p.173-181, 2001.

19 NIKAM, A.K. Genomic fingerprinting of Escherichia coli strains using Repetitive Sequence Based Polymerase Chain Reaction. 2004. 106 p. Thesis (PhD) - Department of Veterinary Microbiology, Gujarat Agricultural University. Anand, 2004

20 NUNES, I. A. Salmonella Enteritidis - fagotipos, susceptibilidade a drogas antimicrobianas e epidemiologia molecular baseada na sonda complementar ao RNA. 1999. 119 p. Tese (Doutorado) - Instituto de Ciências Biomédicas (Microbiologia), Universidade de São Paulo, São Paulo, 1999.

21 OSEK, J. Phenotypic and genotypic characterization of Escherichia coli 0157 strains isolated from humans, cattle and pigs. Veterinary Medicine, v.49, p.317-326, 2002.

22 RIOS, E.R. Detecção de E. coli e E. coli 0157:H7 em superfície de meias-carcaças de bovinos abatidos em estabelecimentos sob inspeção federal em Goiânia-Go. 2005. 72 p. Dissertação (Mestrado em Ciência Animal) Escola de Veterinária, Universidade Federal de Goiás, Goiania, 2005

23 ROHLF, F.J. NTSYS-pc: numerical taxonomy and multivariate analysis system. Version 2.1. New York: Exeter Software, 2000.

24 ROWLANDS, R.E.G; RISTORI, C.A.; FERREIRA, T.; YTO, A.Y.; FRANCO, D.L.; SCOLA, M.C.G.; JAKABI, M.; GELLI, D.S.; TAMPLIN, M.; CUNHA, T.N.; GASPARI, E.N. Produção e aplicação de novos anticorpos monoclonais na padronização de técnicas imunológicas para a detecção das bactérias Escherichia coli O157:H7, Vibrio colerae O1 e toxinas Stx1, Stx2 em alimentos. BEPA - Boletim Epidemiológico Paulista, v.4, n.37, 2007. Disponível em: http://www.cve.saude.sp.gov. br/agencia/bepa37_vibrio.htm. Acesso em: agosto de 2008.

25 SILVA, A.V.C.; MARTINS, A.B.G. Identificação de marcas moleculares associadas à ausência de sementes em videira. Ciência Rural, v.36, n.3, p.801-806, 2006.

26 SILVEIRA, N.F.; SILVA, N.; CONTRERAS, C. Ocorrência de Escherichia coli O157:H7 em produtos cárneos no Brasil. Ciência e Tecnologia de Alimentos, v.21, n.2, p.223-227,1999.

27 STELLA, A.E.; RIGOBELO, E.C.; OLIVEIRA, A.C.; MALUTA, R.P.; MARIN, J.M.; ÁVILA, F.A. Ocorrência e sensibilidade microbiana de linhagens de Escherichia coli enteropatogênicas isoladas de propriedades leiteiras na região de Ribeirão Preto-SP, Brasil. Veterinária e Zootecnia, v.15, n.1, p.66-74, 2008.

28 VAN LITH, L.A.J.T.; AARTS, H.J.M. Polymerase Chain Reaction identification of Salmonella serotypes. Letters in Applied Microbiology, v.19, n.4, p.273-276, 1994.

29 VERSALOVIC, J.; KOEUTH, T.; LUPSKI, J. R. Distribution of repetitive DNA sequences in eubacteria and application to fingerprinting of bacterial genomes. Nucleic Acids Research, v. 19, p. 6823-6831, 1991.

30 WANG, Z.; LUO, T.; ROEDER, R.G. Identification of an autonomously initiating RNA polymerase III holoenzyme containing a novel factor that is selectively inactivated during protein synthesis inhibition. Genes \& Development, v.7, n.11, p.23712382, 1997 